\title{
USING PQ4R TO IMPROVE STUDENTS' READING AT EMERGENCY REMOTE LEARNING
}

\author{
${ }^{1}$ Nia Zupita, ${ }^{2}$ Yayah Nurhidayah, ${ }^{3}$ Eka Nurhidyat \\ Universitas Majalengka, Majalengka, Indonesia
}

1'niazupita2000@gmail.com, ${ }^{2}$ hidayahnur@unma.ac.id, ${ }^{3}$ ekanurhidayat@unma.ac.id

Submitted: 10/ August/2021

Received: 14/August/2021

Published: 8/September/2021

\begin{abstract}
Emergency remote learning is a substitute for face-to-face teaching and learning activities during the COVID-19 pandemic. Students feel various problems in the teaching and learning process, especially reading English text in this study. Students feel uncomfortable, less handling, reading text must be repeated to understand, and the more wanted problems in this study are the mean score of reading students is still lacking. There is no particular method used in reading. Therefore, this study proposed the PQ4R method as a method that could be used to improved students' homework. This research was qualitative and quantitative with the CAR (Classroom Action Research) method, and the data collection techniques were tests and questionnaires. This study also used triangulation as data validation. The mean score of students ' reading has increased from the existing situation, the first cycle, to the second cycle. The current situation means the score was 65.16, the mean score of the first cycle was 78.03, and the mean score of the second cycle was 88.94. In addition, students' responses to the PQ4R method were positive. The results of this study indicated that the PQ4R process could improve students' reading mean scores.
\end{abstract}

Keywords: PQ4R method, students' reading, emergency remote learning, online media, English text

\section{Introduction}

Reading is a process in learning, as well as in online learning conditions. Reading using emergency remote learning has different circumstances. It is not easy for students to obtain reading comprehension indirect meetings and new virtual meetings. Many students encounter difficulty reading in online classes. From deepening the problems carried out at the research location, students admitted that reading in emergency remote learning had an uncomfortable situation and lack of handling. In addition, students can not immediately understand the text in one reading; on average, students need to read three times to understand the text. The several problems described, which affect the most, are students' mean reading scores below the minimum criteria of mastery learning and the absence of a method applied at one of the senior high schools in Majalengka. Therefore the PQ4R method is proposed as a method that can be used. PQ4R method is a method for reading comprehension, abbreviated from the preview, questions, read, reflect, recite, and review. PQ4R method created by Thomas and Robinson in 1972 is one of the strongest candidates because lots of successful research on this and looking at how the system works seems reliable doing at emergency remote learning. Based on various studies conducted, PQ4R was assessed as significantly increasing students' reading comprehension. One of the studies that state this is the research undertaken by Sari et al. (2015) with the conclusion that PQ4R increases the students' reading comprehension in all aspects, especially in understanding vocabulary.

The researchers chose to do this research at one of the senior high schools in Majalengka where appropriate with the opinion of Hayes (in Ebes, 2019: 30) stated that "PQ4R strategy can be applied for high school and college classes to make substantial use of textual materials and it can be used with individual students, small groups, and whole classes". This research conducted examines the use of the PQ4R method in high school like many previous studies. The difference is that the survey used the PQ4R method in 
learning at emergency remote learning, which is usually in field conditions. This is because, one of the schools in Majalengka that became the location of this study conducted online learning or emergency remote learning. While, in research that has been done a lot, the PQ4R procedure is carried out in conventional classroom conditions or face-to-face.

Based on the explanation of the problems and the background described, researchers will examine the PQ4R reading method associated with reading at emergency remote learning. Therefore, researchers are interested in reviewing these problems to become a suitable and helpful method for teachers and students. Researchers formulate several issues: (1) Does implementing the PQ4R method improve students' reading in emergency remote learning? (2) What are the students' responses using the PQ4R method in learning reading at the emergency remote learning?

\section{Literature Review}

Researchers refer to several similar types of research and related researches as a means of helping and forming appropriate information for this research. Some of these studies discuss virtual classrooms in teaching and learning reading and the use of PQ4R. Research conducted by Mercer in 2019 on the scope of online reading discoveries over the past decade has shown that reading print and digital is different, so it requires to practice both fluency and strategies using digital texts. Continuing into the realm of PQ4R, research by Ebes (2019) that has the same variables as this study, namely discussing PQ4R and students' reading, but with a different method, because Ebes uses the experimental method while this study uses the CAR method. The results showed that the PQ4R method made a difference in students' level of understanding, where using PQ4R improved students' reading comprehension. This is because the experimental class has mean score of 78.64, while the control class has mean score of 73.94 .

In detail, several studies can draw about the PQ4R methods, like Pidianto (2017), said that students feel more active and have an excellent response to the PQ4R process. Rajagukguk (2019) also argues that the PQ4R is one strategy that make it easier to learn, especially in reading comprehension. Then as proposed by Fox et al. (in Wahono, 2014), argued that steps in the PQ4R method aim to make readers understand and remember what they read. It is also supported by a detailed statement from Linayaningsih (2011) that in the process, PQ4R makes students listen to the teacher and more so because students participate more by thinking actively to solve problems. Therefore, the PQ4R method can make students better at reading (Wahono, 2014).

\section{Research Methodology}

This research was conducted online using WhatsApp and Google Forms at one of the senior high schools in Majalengka for one month. This study uses WhatsApp and Google Forms media because at the research location, in daily teaching and learning process at ERL these media are the most frequently used. Then, research subjects here were XI MIPA 4 with thirty-three students. Data collection techniques in this research using tests and questionnaires. The test was conducted twice with one test containing twenty multiple choice questions, and the questionnaire was completed once with eight questions about the PQ4R method. The tests were conducted online through Google Forms with questions about reading comprehension in narrative text. The questions in this tests were made independently using aspects contained in Smith (1995) also in Brown (2004). The aspects used are main idea, detail, inference and vocabulary. Besides that, the questionnaire here was developed using a likert scale consisting of five points, namely SA (strongly agree), A (agree), N (neutral), D (disagree), and SD (strongly disagree). According to Nemoto and Beglar (2014) the Likert scale is a psychometric scale consisting of several categories where as a forum for participants to show their responses to their opinions, attitudes and feelings towards an issue. Thus, this questionnaire was a closed-ended question. Then, the questions used in the questionnaire were made based on needs.

Meanwhile, the research method used was the CAR (Classroom Action Research) approach, which according to Khasinah (2013: 107). CAR is "research conducted by a teacher (educator) in a classroom or where he/she teaches that focuses on improving processes and learning praxis." Therefore, it is known that CAR functions as a tool to try or develop a method to fix a problem or improve the quality of classroom learning. Kemmis and McTaggart in Gogus (2012: 70) state action research as "to plan, act, observe and 
reflect more carefully, more systematically, and more rigorously than one usually does in everyday life; and to use the relationships between these moments in the process as a source of both improvement and knowledge." Therefore, in broad terms, action research has four stages: plan, act, observe and reflect, which are carried out in real situations or cases that improve the quality.

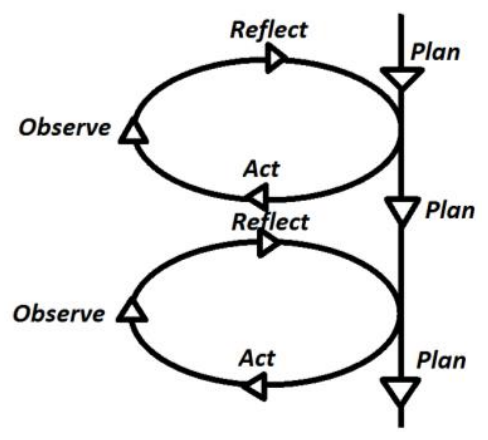

Figure 1 CAR's Cycles

Table 1 CAR's Cycles

\begin{tabular}{|c|c|}
\hline Cycle 1 & Cycle 2 \\
\hline $\begin{array}{l}\text { - Planning } \\
\text { Designing PQ4R class online activities } \\
\text { Make PQ4R test questions } \\
\text { - Acting } \\
\text { Introduce and explain how the PQ4R method } \\
\text { works in the WhatsApp group } \\
\text { Give reading comprehension tests in Google } \\
\text { Form } \\
\text { Observing } \\
\text { Observing students at the class } \\
\text { Check students' test answers } \\
\text { Evaluating the results of the class }\end{array}$ & $\begin{array}{l}\text { - Planning } \\
\text { Designing PQ4R class online activities based on } \\
\text { evaluation from cycle } 1 \\
\text { Make PQ4R test questions } \\
\text { - Acting } \\
\text { Introduce and explain how the PQ4R method } \\
\text { works in the WhatsApp group } \\
\text { Give reading comprehension tests in Google Form } \\
\text { Observing } \\
\text { Observing students at the class } \\
\text { Check students' test answers } \\
\text { E Reflecting } \\
\text { Evaluating the results of the class }\end{array}$ \\
\hline
\end{tabular}

Data validation was also used in this study, carried out to test the validity of the data. The method used in this research is data triangulation. According to Sugiyono, triangulation tests the validity of data obtained from various sources, various ways, and various times (2011: 372). The triangulation is carried out by the data collection techniques and the existing data, which have different styles with the same source.

To find out the results of using the PQ4R reading method, the researchers used quantitative descriptive statistical analysis and qualitative interactive analysis as the data analysis. According to Ghozali, descriptive statistics describe data seen from the mean, standard deviation, variance, maximum, minimum, sum, range, kurtosis, and skewness (slope distribution) values (2018: 19). Therefore, this research will be displayed in a table containing the mean, median, mode, and percentage because these parts are needed. While, interactive analysis technique from Miles\&Huberman. This analysis technique has three component steps, namely data reduction, data display, and conclusion drawing/verification.

\section{Result}

The researcher researched in the first week to observe the situation in the online classroom. In understanding the status of the course, we take an informal personal approach to teachers and students who teach English subjects. The content explored is related to the overall situation of the online classroom and the reading situation of the students. Therefore, as mentioned in the introduction, the researcher found a problem. 
After observing the case at the study site, the researcher performed cycle one in the second week. The first cycle is executed for one week, and the results are shown in the table.

Table 2 Test Result of Cycle 1

\begin{tabular}{|l|c|}
\hline \multicolumn{1}{|c|}{ Researched Item } & Result \\
\hline Total Score & 2575 \\
\hline Mean & 78,03 \\
\hline Lowest Score & 55 \\
\hline Highest Score & 100 \\
\hline Median & 80 \\
\hline Mode & 90 \\
\hline Number of Passed & 19 \\
\hline Number of Failed & 14 \\
\hline Passed Percentage & $57.58 \%$ \\
\hline Failed Percentage & $42.42 \%$ \\
\hline
\end{tabular}

The researcher carried out cycle 2 in the third week after observing the situation at the research site and conducting the first cycle. The implementation of the second cycle was carried out for one week, with the results as in the table.

Table 3 Test Result of Cycle 2

\begin{tabular}{|l|c|}
\hline \multicolumn{1}{|c|}{ Researched Item } & Result \\
\hline Total Score & 2935 \\
\hline Mean & 88,94 \\
\hline Lowest Score & 50 \\
\hline Highest Score & 100 \\
\hline Median & 90 \\
\hline Mode & 90 \\
\hline Number of Passed & 31 \\
\hline Number of Failed & 2 \\
\hline Passed Percentage & $93,94 \%$ \\
\hline Failed Percentage & $6,06 \%$ \\
\hline
\end{tabular}

Student responses were carried out to strengthen and prove the tests carried out in both cycles. The researcher collected responses through a questionnaire given to students who had used the PQ4R method in two weeks of learning or two processes. The questionnaire distributed was related to the application of the PQ4R method in reading students in online classes. The condition and material understanding are examined in the questionnaire application of the PQ4R method in reading students.

Table 4 Result of Questionnaires

\begin{tabular}{|l|l|c|c|c|c|c|}
\hline \multicolumn{1}{|c|}{ Item } & SA & A & N & D & SD \\
\hline $\begin{array}{l}\text { After using the PQ4R method, does it } \\
\text { feel easier to understand the reading } \\
\text { in the online class? }\end{array}$ & Freq. & 12 & 15 & 6 & 0 & 0 \\
\cline { 2 - 7 } & Percentage & $36,4 \%$ & $45,5 \%$ & $18,2 \%$ & $0 \%$ & $0 \%$ \\
\hline $\begin{array}{l}\text { Are you comfortable using the PQ4R } \\
\text { method? }\end{array}$ & Freq. & 12 & 13 & 8 & 0 & 0 \\
\cline { 2 - 7 } & Percentage & $36,4 \%$ & $39,4 \%$ & $24,2 \%$ & $0 \%$ & $0 \%$ \\
\hline $\begin{array}{l}\text { Do you think the PQ4R method takes } \\
\text { a little time? }\end{array}$ & Freq. & 3 & 7 & 15 & 6 & 2 \\
\cline { 2 - 7 } & Percentage & $9,1 \%$ & $21,2 \%$ & $45,5 \%$ & $18,2 \%$ & $6 \%$ \\
\hline $\begin{array}{l}\text { Does PQ4R make you more } \\
\text { concentrated and focused on reading } \\
\text { comprehension? }\end{array}$ & Freq. & 9 & 17 & 7 & 0 & 0 \\
\hline $\begin{array}{l}\text { Can PQ4R get information in text } \\
\text { faster, so you do not read the text be } \\
\text { repeated as much as before? }\end{array}$ & Freq. & $27,3 \%$ & $51,5 \%$ & $21,2 \%$ & $0 \%$ & $0 \%$ \\
\cline { 2 - 7 } & Percentage & $21,2 \%$ & $60,6 \%$ & $15,2 \%$ & $3 \%$ & $0 \%$ \\
\hline $\begin{array}{l}\text { Do you feel that you understand the } \\
\text { text better when using the PQ4R } \\
\text { method than when you do not? }\end{array}$ & Freq. & 6 & 20 & 7 & 0 & 0 \\
\cline { 2 - 8 } & Percentage & $18,2 \%$ & $60,6 \%$ & $21,2 \%$ & $0 \%$ & $0 \%$ \\
\hline Do you feel any improvement in & Freq. & 6 & 17 & 10 & 0 & 0 \\
\hline
\end{tabular}


IJEAL (International Journal of English and Applied Linguistics)

Volume : 1 | Number 2 | August 2021 | E-ISSN : 2787-9482 | DOI: doi.org/ijeal.v1n1.1052

\begin{tabular}{|l|l|c|c|c|c|c|}
\hline $\begin{array}{l}\text { reading comprehension from the first } \\
\text { use to the second use? }\end{array}$ & Percentage & $18,2 \%$ & $51,5 \%$ & $30,3 \%$ & $0 \%$ & $0 \%$ \\
\hline $\begin{array}{l}\text { Does the PQ4R method make you } \\
\text { independent } \\
\text { comprehension? }\end{array}$ & Freq. & 7 & 18 & 8 & 0 & 0 \\
\cline { 2 - 7 } & Percentage & $21,2 \%$ & $54,5 \%$ & $24,2 \%$ & $0 \%$ & $0 \%$ \\
\hline
\end{tabular}

Triangulation of test results for each cycle and questionnaire was carried out after both data were available. This triangulation was carried out as a validation of the two data to prove and strengthen their truth. The results of the triangulation or combination can be seen in the table.

Table 5 Result of Triangulation

\begin{tabular}{|l|l|}
\hline \multicolumn{1}{|c|}{ Test } & \multicolumn{1}{c|}{ Questionnaire } \\
\hline $\begin{array}{l}\text { Cycles } 1 \\
\text { There was an increase in students' reading scores in } \\
\text { the first cycle compared to the existing scores. The } \\
\text { mean score of existing students or without using the } \\
\text { PQ4R method was below the minimum criteria of } \\
\text { mastery learning, 65.16. While, when using PQ4R } \\
\text { in the first cycle, the student's mean score was } \\
\text { 78.03. }\end{array}$ & $\begin{array}{l}\text { Cycles } 1 \\
\text { students, the PQ4R method made it easier for them to } \\
\text { understand reading in emergency remote learning, made it } \\
\text { comfortable to used, the time used was calculated to fit, } \\
\text { makes it more concentrated and directed, makes it easier to } \\
\text { get information in the text, made easier to understand the text } \\
\text { than not using PQ4R and made independent. }\end{array}$ \\
$\begin{array}{l}\text { Cycles } 2 \\
\text { There was an increase in students' reading scores in } \\
\text { the second cycle compared to the first cycle. The } \\
\text { mean score of students in the first cycle was 78.03, } \\
\text { while the mean score of students in the second cycle } \\
\text { was 88.94. }\end{array}$ & $\begin{array}{l}\text { Cycles 2 } \\
\text { The results of the questionnaire showed that according to } \\
\text { students, the PQ4R method made it easier for them to } \\
\text { understand reading in emergency remote learning, made it } \\
\text { comfortable to used, the time used was calculated to fit, } \\
\text { made it more concentrated and directed, made it easier to get } \\
\text { information in the text, made easier to understand the text } \\
\text { than not using PQ4R and made independent. In addition, } \\
\text { students also agreed that they felt an increased in using the } \\
\text { PQ4R method in the second cycle compared to the first } \\
\text { cycle. }\end{array}$ \\
\hline
\end{tabular}

\section{Discussion}

1. Does implementing the PQ4R method improve students' reading in emergency remote learning?

The reading method is essential for students, especially in English lessons where students find it more difficult. The results obtained show the scores that showed how the influenced of one reading method on students' reading. The method used here is the PQ4R method which has proven its effectiveness from previous researches. In this research, the existing score became the primary benchmark for increasing the PQ4R way, which was carried out in two cycles.

In the early condition, students felt many difficulties in reading English texts in emergency remote learning. Thus, the reading scores of existing students or without using the PQ4R method still have not reached the minimum criteria of mastery learning, where the minimum standards of mastery learning are 75 . Meanwhile, the mean score of students' reading in the test is 65.16 .

Chart 1 Mean of Exiting Score 


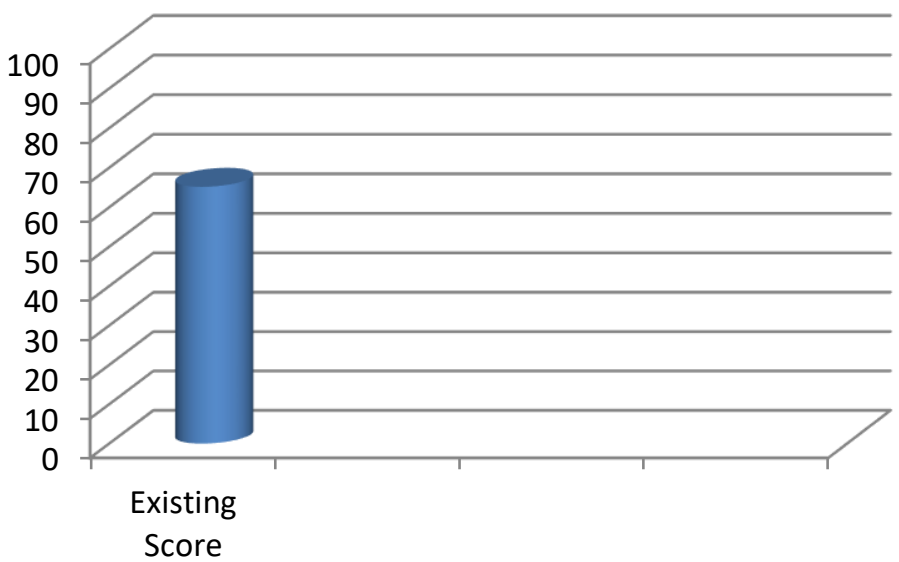

In the first cycle, we introduced and explained the PQ4R method and conducted a reading test using that method. Students said that they understand enough to justify the way and have understood how the technique works. The use of online media as a means of delivering material is also conducive. From the test results, it can be seen that there is a difference between the existing mean score and the mean score of the reading test using the PQ4R method, where the mean score of this cycle is 78.03. The score of students in this cycle has a median score of 80 , and the score that many students get is 90 . These scores also found that $57.58 \%$ of students have scores exceeding the minimum criteria of mastery learning. The change can be seen from the graph below.

Chart 2 Mean Score of Exiting and Cycle 1

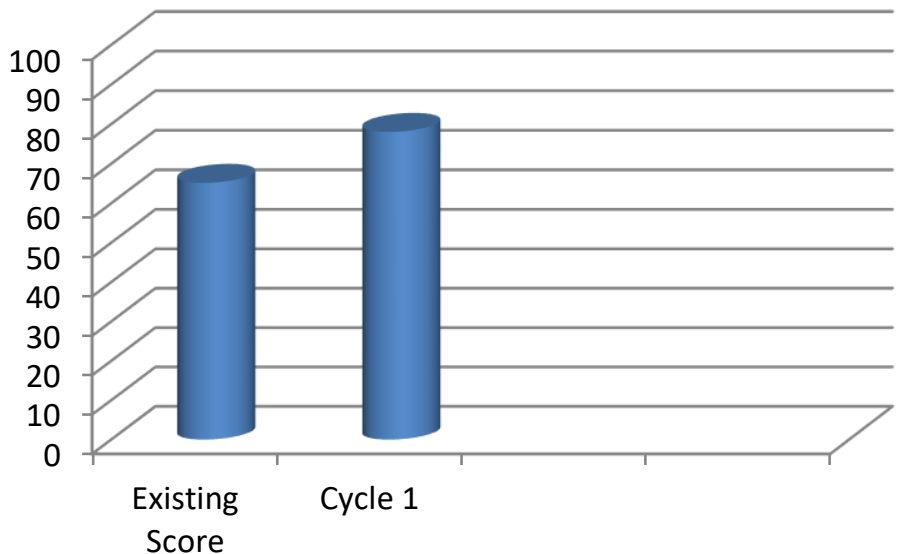

Then the second cycle explained the PQ4R method again to the students and did the second test. In this cycle, to increased the effectiveness of supporting media, The researcher enhanced the use of online media to deliver material and communication by taking a more intensive approach to students. The results showed that the mean score of students' reading in this cycle increased from the previous process, 88.94. The median score is the same as the score that appears most often, which is 90 . The results of the percentage of passed of this cycle are $93.94 \%$, and $6.06 \%$ did not pass. The increase can be seen from the graph below.

Chart 3 Mean Score of Exiting, Cycle 1 and Cycle 2 


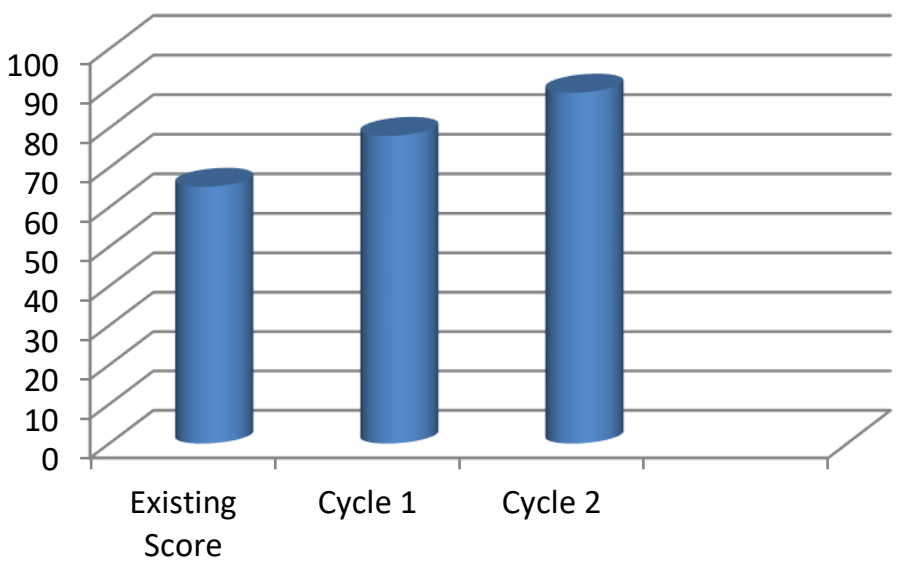

The results of these tests indicated that the implementation of the PQ4R method improved students' reading. This can be seen from comparing existing scores with student test results when using the PQ4R method in each cycle. Students' scores have increased from existing scores that do not use the PQ4R form with those obtained in the process where the PQ4R method is used. At which first, the current student scores were 65.16, then increased in the first cycle to 78.03, then rose in the second cycle to 88.94. The results obtained in this research are the same as those obtained in previous studies from Sari et al., 2015; Khusniyah, 2018; Rahmini et al., 2018; Abidin, 2019; and Ebes, 2019, which they research showed that PQ4R improved students' reading comprehension.

The difference between the first cycle and the second cycle was the score obtained, where the second cycle has a higher score. In addition, in practice on the second cycle, a more intensive approach was taken, which was an improvement that was obtained after conducting an evaluation in the first cycle. With this approach, students are expected to be more focused and motivated. However, besides that, it can be concluded that the first and second cycles have similarities globally.

2. What are the students' responses using the PQ4R method in learning reading at the emergency remote learning?

After doing a series of cycles for two weeks, last week, a collection of student responses was conducted to find out more about using the PQ4R method that had been carried out. The questionnaire results to the students showed that the student's response was good to the PQ4R process. The questionnaires revealed that students found it easier to use the PQ4R method in understanding reading in emergency remote learning. Students felt comfortable using the PQ4R method. The time used in implementing the PQ4R process was considered not too long and not too fast. The PQ4R form also made students more concentrated and focused on understanding reading. Students could also understand texts more quickly using the PQ4R method, so they do not read it repeated as much as before. Besides that, students felt the PQ4R process better understand a text, and in using the PQ4R method in the first cycle with the second cycle, students think increased. The last was that students felt they could be more independent in understanding the text guided by the PQ4R method. Therefore, overall the results obtained from the students' responses in this questionnaire stated that students agreed that $\mathrm{PQ} 4 \mathrm{R}$ was a good method in their reading, similar to the responses of students in research from Pidianto (2017) which in this study students had good responses to the PQ4R method. From these student responses, it can also be concluded that the writer can also finish helpful in students' reading comprehension, in line with Wahono's opinion (2014) in his research which has a statement that the PQ4R method can make students understand reading better.

The mean score exceeds the minimum criteria of mastery learning in the first cycle, then the existing score at the research location without using the PQ4R method. These results are appropriate with the questionnaires filled out by students who claimed that the PQ4R approach positively impacted reading comprehension than before or not using it, especially in emergency remote learning conditions. This proves that the test results and the questionnaire results run in one direction and strengthen the results by establishing the questionnaire, which is a student statement. 
Then, in the second cycle, the mean score of students increased from the previous process. These results are by the results of the questionnaire, which in addition to stating that the PQ4R method has a positive impact. Students feel an improvement from the first week (cycle 1) to the second week (cycle 2)supported by student statements in the field during this cycle which stated that their use of the PQ4R method was getting better. The PQ4R process proves that the test results that present the student actions and the questionnaire results that show the student opinions are synchronous and more robust conclusions.

\section{Conclusion}

Research for two cycles in two weeks showed that the PQ4R method could improve students' reading scores in emergency remote learning. It is evident from the increase in the mean score of students. Starting from the existing score of 65.16 , then increasing in cycle one with a mean score of 78.03, then increasing again in cycle two by reaching the highest mean score of 88.94 . These scores indicated that the reading method greatly influences students' reading.

In addition, to strengthen the data, a survey was conducted with a questionnaire to find out the results of students' opinions. The results obtained, the students' response after using the PQ4R method was good. The participants' agreement in this study on the effectiveness of applying the PQ4R approach in ERL demonstrates these findings. The results of the student questionnaire as students' responses can be concluded into two aspects, namely condition and material understanding. Regarding requirements, students found it easier to understood text in ERL using the PQ4R method. Also, students felt comfortable in the process of using it. Still, the time used in operating the PQ4R way was not a little but also not too much. Then, regarding material understanding, students felt more concentrated and directed in understanding the text, students also feel they can focus more so they don't repeat reading a lot, students feel better understanding texts using the PQ4R method than not, students also felt that they have improved from the first time using PQ4R to the second use, and students felt more independent in reading comprehension by holding the PQ4R method.

\section{References}

Abidin, A. (2019). The Use of PQ4R Method to Improve Students' Reading Comprehension (A Case Study conducted at Eleventh Grade of SMAN 4 Gorontalo for Academic Year 2018/2019)(Thesis Skripsi). Available UNG Repository.

Brown, D. (2004). Language Assessment: Principle and Classroom Practice. San Francisco: Longman.

Ebes, M. N. (2019). PQ4R Strategy In Eleventh Grade Students' Reading Comprehension Achievement on SMA Darul 'Ulum 1 Jombang. RETAIN, 7(2), 29-37.

Fox, R., Radloff, A., \& Herrmann, A. (1994). Learning Skills. Teaching Learning Group. Bentley: WA.

Ghozali, I. (2018). Aplikasi Analisis Multivariate dengan Program SPSS 25 (9th ed.). Semarang: Badan Penerbit Universitas Diponegoro.

Gogus, A. (2012). Action Research on Learning. Encyclopedia of the Sciences of Learning, 67-72.

Hayes, D. A. (1992). A Sourcebook of Interactive Methods for Teaching with Texts. Boston: Allyn\&Bacon.

Kemmis, S., \& McTaggart, R. (1988). The Action Research Planner (3 ed.). Geelong: Deakin University.

Khasinah, S. (2013). Classroom Action Research. Jurnal Pionir, 1(1), 107-114.

Khusniyah, N. L. (2018). The Impact of PQ4R Strategy Use on EFL Students' Reading Comprehension. Edulangue: Journal of English Language Education, 1(2), 166-177. 
Linayaningsih, F. (2011). Metode PQ4R (Preview, Question, Read, Reflect, Recite,Review) Untuk Meningkatkan Prestasi Belajar Pendidikan Kewarganegaraan. Majalah Ilmiah INFORMATiKA, 2(2), 75-86.

Mercer, N. B. (2019). Online Reading Strategies for the Classroom. English Teaching Forum, 57(4), 2-11.

Miles, M. B., \& Huberman, A. M. (1984). Qualitative Data Analysis.

Nemoto, T., \& Beglar, D. (2014). Developing Likert-Scale Questionnaires. In N. Sonda \& A. Krause (Eds.). JALT2013 Conference Proceedings. Tokyo: JALT.

Pidianto, A. (2017). The Effectiveness of PQ4R Method to the Eighth Grade Students' Reading Comprehension of SMP Muhammadiyah Kediri in the Academic Year 2016/2017 (Skripsi). Available from Journal of Sistem Informasi Manajemen Karya Ilmiah Universitas Nusantara PGRI.

Rahmini, S., Delfi, S., \& Sumbayak, D. M. (2018). The Effect of Using PQ4R Method on The Ability of The First Year Students of SMK Pesantren Darel Hikmah Pekanbaru in Comprehending Recount Texts. Jurnal Online Mahasiswa Fakultas Keguruan dan Ilmu Pendidikan, 5(2), 1-7.

Rajagukguk, S. M., Tarigan, K. E., \& Ginting, F. Y. (2019). Improving The Students' Reading Comprehension by Using PQ4R Strategy to the Eighth Grade at SMP Negeri 2 Pancur Batu. KAIROS ELT JOURNAL, 3(2), 93-107.

Sari, R. Y., Sudirman, \& Supriyadi, D. (2015). The Effect of PQ4R Strategy in Reading Comprehension Achievement. UNILA Journal of English Teaching, 1-15.

Smith, D. B. (1995). Breaking through Collage Reading. New York: Harper Colins Collage Publisher.

Sugiyono. (2011). Metode Penelitian Kuantitatif, Kualitatif, dan R\&D. Bandung: Alfabeta.

Thomas, E. L., \& Robinson, H. A. (1972). Improving Memory in Every Class: A Sourcebook for Teachers. Boston: Allyn\&Bacon.

Wahono, S. S. (2014). Using PQ4R to Increase the Students' Reading Comprehension at Al-Bidayah Islamic Boarding School Jember. FENOMENA, 13(2), 121-132. 